\title{
UJI LAMA PERENDAMAN STEK LADA (PIPER NIGRUM L) PADA EKTRAK TAUGE TERHADAP PERTUMBUHAN AKAR DAN TUNAS
}

\author{
Murdaningsih, Philipus N Supardi dan Fransiskus Soge \\ Fakultas Pertanian-Universitas Flores \\ Jalan Sam Ratulangi XX Paupire, Ende-Flores Nusa Tenggara Timur \\ murdaningsih11@gmail.com
}

\begin{abstract}
Old testing floating pepper (Piger nigrum $\mathrm{I}$ ) on tauge extract to root and shoulder growth. The study was intended to determine the growth response of the pepper plant steak due to an extended 3 hours of Tauge extracting with a concentration of $300 \mathrm{ml} / \mathrm{l}$. The design used in this study is a completely random design with a single factory based pattern of P1 (1 hour), P2 (2 hours), P3 (3 hours), P4 (4 hours), P5 (5 hours). Variable observations in this study are the number of shoots (strands), length of shoots $\left(\mathrm{cm}^{2}\right)$, number of leaves (strands), amount of roots $\left(\mathrm{cm}^{2}\right)$, length of roots $(\mathrm{cm} 2)$, fresh shoots (gram), shoots dry weights (gram), root fresh weights (gram), root dry weights (gram), root dry weights (gram). Studies indicate that extended snorting time of pepper on and Tauge extracting gives very real influence to the growth variable of sprouts $(50,66 \%)$, root length $(32,96 \%)$, leaves $(58,88 \%)$, root length $(45,14 \%)$, root weight $(57,72 \%)$, shoots $(71,43 \%)$, shoots dry weight $(65,73 \%)$. Thus the treatment of Tauge extracts as one of the natural growth regulator plants in seeding with a concentration of $300 \mathrm{~m} / 1$ water would be best submerged for 3 hours to speed up the growth and remove the roots to achieve the best quality of the steed growth.
\end{abstract}

Keywords: extract tauge, pepper wire, long immesion

\section{PENDAHULUAN}

Indonesia sejak masa penjajahan dikenal sebagai pengahasil rempahrempah, salah satunya adalah Lada. Akan tetapi pada kenyataannya terdapat penurunan produksi. Indonesia juga merupakan salah satu negara pengekspor lada (Piper nigrum L) di dunia. Produksi lada tahun 2016 mencapai 82,17 ribu ton dan tahun 2017 mencapai 82,96 ribu ton (Direktorat Jendral Perkebunan, 2016). Ekspor lada Indonesia mencapai 53,10 ribu ton. Tetapi masih impor lada tahun 2016 mencapai 2.663 ton dan pada tahun 2017690 ton. Untuk itu masih sangat 
diperlukan upaya peningkatan produksi, melalui teknik budidaya, yang salah satu diantaranya dengan melakukan perbanyakan tanaman secara vegetatif (Direkttorat Budidaya Tanaman Rempah dan Pagar, 2008).

Kendala dalam perbanyakan tanaman lada dengan mengunakan stek sering kali mengalami kegagalan dengan tidak tumbuhnya akar sehingga dibutuhkan suatu teknologi yang mampu meningkatkan pertumbuhan perakaran dan tunas. Salah satu alternatif yang dapat di lakukan yaitu dengan mengunakan zat pengatur tumbuh (ZPT) untuk merangsang pertumbuhan perakaran dan tunas pada stek, sehingga memperkecil resiko kegagalan. ZPT merupakan senyawa organik yang bukan hara dimana dalam jumlah tertentu dapat aktif merangsang ataupun menghambat pertumbuhan dan perkembangan tanaman. Berdasarkan sumbernya ZPT dapat diperoleh baik secara alami maupun sintetis. Pengunaan ZPT alami lebih menguntungkan dibandingkan ZPT sintetis, karena harganya murah, mudah didapat, danramah lingkungan. Salah satu sumber ZPT alami yang
Teknik perbanyakan tanaman lada secara vegetatif banyak di lakukan karena tanaman lebih cepat berproduksi, pertumbuhan seragam serta mempunyai sifat yang sama dengan induknya.

dapat digunakan adalah tauge atau kecambah dari kacang hijau. Ekstrak tauge mengandung sitokinin, auksin, dan giberalin (Abdullah, Maulana Wulandari, Nirwana, 2019).

Menurut Amilah dan Astuti (2006), sitokinin merupakan salah satu ZPT yang berfungsi memacu pembelahan sel dan organ, mencegah kerusakan klorofil, serta perkembangan tunas. Auksin juga berfungsi mendorong perpanjangan sel, pembelahan sel, diferensiasi jaringan xilem dan floem, pembentukan akar, serta menghambat penguguran daun. Zat pengatur tumbuh giberalin juga berperan dalam pertumbuhan dan perkembangan tanaman yakni memacu pertumbuhan sel mengarah kepada pemanjangan batang dan perkembangan daun.

Kecambah kacang hijau (tauge) mengandung komponen air, gula dalam bentuk sukrosa, fruktosa, dan glukosadanAsam amino esensial 
Murdaningsih : Uji lama perendaman stek lada pada ekstrak tauge

antara lain triptofan $1,35 \%$,treonin $4,50 \%$, fenilalanin $7,07 \%$ metionin $0,84 \%$, lisin $7,94 \%$ leusin, $12,90 \%$ isoleusin, $6,95 \% \quad$ valin, $6,25 \%$. Rismunandar (1992) dalam Amilah dan Astuti (2006), triptofan merupakan bahan baku sintesis IAA. Triptofan berperan sebagai prekursor biosintesis auksin/ IAA (Indol-3 -Acetic Acid) . IAA merupakan jenis hormon auksin endogen yang banyak disintesis pada akar, batang, dan berperan penting dalam prbanyakan vegetatif tanaman. Hormon auksin juga berfungsi untuk memacu pertumbuhan karena dapat merangsang pembesaran sel, sintesis DNA kromosom, serta merangsang pertumbuhan akar tanaman (Sari, 2011).

Menurut Budianto E.A, Kaswan Badami dan Ahmad Arsyadmunir (2013) menyatakan bahwa perlakuan lama perendaman dengan IBA (Indole Butryc Acid) yang mempunyai kandungan hormon tumbuh auksin $(0,057 \%)$ direndam selama 3 jam memberikan pengaruh secara nyata terhadap parameter Panjang Akar (6,65 cm), Jumlah
Daun $(5,10)$ dan Bobot Kering Akar $(6,37$ g) pada stek tanaman sirih merah.

$\begin{array}{rrr}\text { Menurut } & \text { Rauzan } \\ \text { Marlina, dan } & \text { Mariana, (2017) }\end{array}$ mengatakan bahwa pengaruh ekstrak tauge dengan konsentrasi 300 ml/l air memberikan hasil terbaik pada rata rata panjang tunas $(9,1 \mathrm{~cm})$ jumlah tunas $(4,0)$ panjang akar $(4,3 \mathrm{~cm})$ dan jumlah akar $(4,2)$ pada tanaman lada.

Berdasarkan uraian diatas maka perlu dipelajari bagaimana respon pertumbuhan akar dan tunas stek tanaman lada akibat lama perendaman pada ekstrak tauge.

\section{METODE PENELITIAN}

\section{Tempat dan Waktu Penelitian}

Penelitian dilaksanakan pada bulan november 2018 sampai maret 2019. Pelaksanaan dilakukan di kebun contoh Fakultas Pertanian, kelurahan lokoboko Kecamatan Ndona Kabupaten Ende.

\section{Bahan dan Alat}

Bahan yang digunakan dalam penelitian ini adalah, tanah top soil, pupuk kompos, stek lada, ekstrak tauge, air. Sedangkan, alat-alat yang 
digunakan dalam penelitian ini adalah polibeg $(16 \times 28 \mathrm{~cm})$, gelas ukur, cangkul, timbangan, meteran, blender, saringan, ember, kertas label, gunting stek, alat tulis dan alat dokumentasi .

\section{Rancangan Penelitian}

Penelitianmenggunakan

Rancangan Acak Lengkap (RAL) dengan pola faktor tunggal yang terdiri dari lima perlakuan lama perendaman yaitu: $\mathrm{P} 1=1$ jam, $\mathrm{P} 2=2$ jam, P3= 3 jam, P4= 4 jam, P5= 5 jam dengan

konsentrasilarutanekstraktauge $\quad 300$ $\mathrm{ml} / \mathrm{l}$ air. Perlakuan di ulang empat kali, dimana masing - masing perlakuan terdiri dari 8 polibag sehingga terdapat 160 polibag.

\section{Variabel Pengamatan}

Variabel Pengamatanantara lain jumlah tunas (helai), panjang tunas (cm), jumlah daun (helai), panjang akar $(\mathrm{cm})$, jumlah akar (helai) bobot segar tunas $(\mathrm{g})$, bobot kering tunas (g), bobot segar akar (g), bobot kering akar (g), yang diamatipadaumur4 mst, $6 \mathrm{mst}, 8 \mathrm{mst}, 10 \mathrm{mst}, 12 \mathrm{mst}$

\section{Analisis Data}

Data hasil pengamatan dianalisis dengan mengunakan analisis sidik ragam. Apabila perlakuan menunjukan pengaruh yang nyata atau sangat nyata terhadap variabel yang di amati maka pengujian dilanjutkan dengan uji beda rata-rata mengunakan uji BNT 5\%. (Gomez dan Gomez, 2007).

\section{HASIL DAN PEMBAHASAN}

Hasilpenelitian yang sudahdianalisis statistik menunjukan bahwa lama waktu perendaman ekstrak tauge dengan konsentrasi larutan $300 \mathrm{ml} / \mathrm{l}$ air berpengaruh sangat nyata terhadap variabel jumlah tunas, panjang tunas, jumlah daun, jumlah akar, panjang akar, bobot segar tunas, bobot kering tunas, bobot segar akar, dan bobot kering akar pada umur pengamtan 8,10 , dan12 mst.

Hasil analisis menunjukkan adanya perbedaan yang nyata pada variabel pertumbuhan akibat lama perendaman pada ekstrak tauge terhadap pertumbuhan akar dan tunas stek tanaman lada (Piper nigrum L). Tetapi tidak berpengaruh nyata pada 
Murdaningsih : Uji lama perendaman stek lada pada ekstrak tauge

umur 4, dan 6 minggu setelah tanam. Hal ini diduga zat pengatur tumbuh (ZPT) alami yang mengandung auksin yang bersumber dari ektrak tauge belum berpengaruh terhadap akar yang masih sangat sedikit sehingga proses pembelahan sel yang terjadi pada stek belum optimal dan belum terlihat pengaruhnya secara signifikan. Sedangkan pada pengamatan $8,10,12$, menunjukan pengaruh sangat nyata disebabkan karena perendaman stek dalam larutan ekstrak tauge yang mengandung hormon tumbuh auksin mulai mempengaruhi akar yang sudah aktif tumbuh sehingga dapat merangsang pertumbuhan akar dan tunas pada stek lada.

\section{Respon Pertumbuhan Tunas Stek Tanaman Lada}

Berdasarkan hasil analisis statistik menunjukan bahwa lama perendaman stek lada pada ekstrak tauge dengan konsentrasi $300 \mathrm{ml} / \mathrm{l}$ air dapat memberi pengaruh yang sangat nyata terhadap pertumbuhan jumlah tunas, panjang tunas, jumlah daun, Berat segar tunas dan Berat kering tunas pada umur $8,10,12$, mst. Dimana perlakuan perendaman selama 3 jam menunjukkan pertumbuhan tunas yang terbaik dan berbeda nyata dengan perlakuan lainnya (Tabel 1).

Hasil penelitian menunjukkan bahwa pada perlakuan P3 (lama perendaman 3 jam) menunjukan pengaruh yang paling tinggi terhadap rata-rata pertumbuhan jumlah tunas (2,28), panjang tunas $(17,05 \mathrm{~cm})$, jumlah daun (3.91), Berat Segar tunas $(4,37 \mathrm{~g})$ dan Berat Kering tunas $(0,74)$ dibandingkan dengan perlakuan lainya pada umur pengamatan $8,10,12$ minggu setelah tanam. Hasil penelitian menunjukkan bahwa pada perlakuan P3 (lama perendaman 3 jam) menunjukan pengaruh yang paling tinggi terhadap rata-rata pertumbuhan jumlah tunas (2,28), panjang tunas $(17,05 \mathrm{~cm})$, jumlah daun (3.91), Berat Segar tunas $(4,37 \mathrm{~g})$ dan Berat Kering tunas $(0,74)$ dibandingkan dengan perlakuan lainya pada umur pengamatan 8, 10, 12 minggu setelah tanam. 
AGRICA, VOL. 12, NO. 2 (2019)

Tabel 1. Pengaruh Lama Perendaman padaEkstrak Tauge Terhadap Pertumbuhan Jumlah Tunas (helai), Panjang Tunas (cm ), JumlahDaun (Helai), Berat Segar Tunas (g)danBeratKering Tunas (g)Stek Tanaman Lada.

\begin{tabular}{|c|c|c|c|c|c|c|c|}
\hline \multirow{2}{*}{ Variabel } & \multirow{2}{*}{ Perlakuan } & \multicolumn{5}{|c|}{ Umur Pengamatan Mst } & \multirow{2}{*}{ Rata-Rata } \\
\hline & & 4 & 6 & 8 & 10 & 12 & \\
\hline Jumlah & $1 \mathrm{Jam}$ & 1,0 & 1,0 & $2,3 \mathrm{a}$ & $1,3 \mathrm{a}$ & $1,0 \mathrm{a}$ & 1,12 \\
\hline \multirow[t]{4}{*}{ Tunas } & $2 \mathrm{Jam}$ & 0,0 & 1,8 & $2,0 \mathrm{~b}$ & $1,5 \mathrm{a}$ & $1,8 \mathrm{ab}$ & 1,31 \\
\hline & $3 \mathrm{Jam}$ & 1,5 & 1,8 & $2,8 \mathrm{bc}$ & $2,8 \mathrm{c}$ & $2,5 \mathrm{c}$ & 2,28 \\
\hline & $4 \mathrm{Jam}$ & 1,0 & 1,5 & $2,3 \mathrm{~b}$ & $2,0 \mathrm{ab}$ & $1,3 \mathrm{a}$ & 1,72 \\
\hline & $5 \mathrm{Jam}$ & 1,0 & 1,2 & $2,0 \mathrm{~b}$ & $1,5 \mathrm{a}$ & $1,5 \mathrm{a}$ & 1,44 \\
\hline BNT 5\% & & Tn & Tn & 0,64 & $\mathbf{0 , 7 8}$ & 0,67 & \\
\hline Panjag & $1 \mathrm{Jam}$ & 7,1 & 12,2 & $11,4 \mathrm{a}$ & $15,1 \mathrm{a}$ & $11,4 \mathrm{a}$ & 11,45 \\
\hline \multirow[t]{4}{*}{ Tunas } & $2 \mathrm{Jam}$ & 8,2 & 10,2 & $12,1 \mathrm{a}$ & $14,0 \mathrm{a}$ & $13,2 \mathrm{a}$ & 11,54 \\
\hline & $3 \mathrm{Jam}$ & 9,1 & 11,9 & $22,1 \mathrm{~b}$ & $21,1 \mathrm{~b}$ & $21,1 \mathrm{~b}$ & 17,05 \\
\hline & 4 Jam & 8,3 & 15,5 & $13,0 \mathrm{a}$ & $20,3 \mathrm{ab}$ & $18,3 \mathrm{ab}$ & 15,09 \\
\hline & 5 Jam & 7,9 & 10,2 & $12,4 \mathrm{a}$ & $13,0 \mathrm{a}$ & $16,3 \mathrm{a}$ & 11,95 \\
\hline BNT 5\% & & Tn & Tn & 4,47 & 6,6 & 6,31 & \\
\hline Jumlah & $1 \mathrm{Jam}$ & 0,0 & 0,0 & $2,5 \mathrm{a}$ & $2,5 \mathrm{a}$ & $3,8 \mathrm{a}$ & 1,76 \\
\hline \multirow[t]{4}{*}{ Daun } & $2 \mathrm{Jam}$ & 0,3 & 0,1 & $2,8 \mathrm{a}$ & $2,8 \mathrm{a}$ & $4,5 \mathrm{a}$ & 2,08 \\
\hline & $3 \mathrm{Jam}$ & 0,8 & 0,2 & $5,0 \mathrm{~b}$ & $6,3 \mathrm{~b}$ & $7,3 \mathrm{~b}$ & 3,91 \\
\hline & 4 Jam & 0,8 & 0,2 & $3,3 \mathrm{a}$ & $4,0 \mathrm{a}$ & $5,0 \mathrm{ab}$ & 2,65 \\
\hline & $5 \mathrm{Jam}$ & 0,3 & 0,1 & $3,5 \mathrm{ab}$ & $2,5 \mathrm{a}$ & $4,0 \mathrm{a}$ & 2,06 \\
\hline BNT 5\% & & TN & TN & 1,04 & 1,63 & 1,75 & \\
\hline Bobot & $1 \mathrm{Jam}$ & 0,1 & 1,4 & $3,0 \mathrm{a}$ & $1,4 \mathrm{a}$ & $3,8 \mathrm{a}$ & 1,94 \\
\hline Segar & $2 \mathrm{Jam}$ & 0,5 & 0,9 & $3,9 \mathrm{a}$ & $1,6 \mathrm{a}$ & $3,7 \mathrm{a}$ & 2,12 \\
\hline \multirow[t]{3}{*}{ Tunas } & 3 Jam & 0,8 & 2,8 & $5,8 \mathrm{~b}$ & $5,1 \mathrm{~b}$ & $7,4 a b$ & 4,37 \\
\hline & $4 \mathrm{Jam}$ & 0,5 & 1,6 & $4,4 \mathrm{a}$ & $2,9 a b$ & $5,6 \mathrm{a}$ & 3,01 \\
\hline & $5 \mathrm{Jam}$ & 0,1 & 0,6 & $3,7 \mathrm{a}$ & $2,8 \mathrm{a}$ & $3,7 \mathrm{a}$ & 2,18 \\
\hline BNT 5\% & & $\mathrm{TN}$ & $\mathrm{TN}$ & 1,38 & 1,88 & 2,09 & \\
\hline Bobot & 1 Jam & 0,1 & 0,2 & $0,4 \mathrm{a}$ & $0,2 \mathrm{a}$ & $0,2 \mathrm{a}$ & 0,21 \\
\hline Kering & $2 \mathrm{Jam}$ & 0,1 & 0,2 & $0,5 \mathrm{a}$ & $0,3 \mathrm{a}$ & $0,4 \mathrm{a}$ & 0,30 \\
\hline \multirow[t]{3}{*}{ Tunas } & 3 Jam & 0,4 & 0,4 & $1,0 \mathrm{~b}$ & $0,9 a b$ & $1,0 \mathrm{~b}$ & 0,74 \\
\hline & 4 Jam & 0,1 & 0,3 & $0,8 \mathrm{ab}$ & $0,5 \mathrm{a}$ & $0,8 \mathrm{ab}$ & 0,50 \\
\hline & $5 \mathrm{Jam}$ & 0,1 & 0,2 & $0,6 \mathrm{a}$ & $0,5 \mathrm{a}$ & $0,2 \mathrm{a}$ & 0,33 \\
\hline BNT $5 \%$ & & $\mathrm{TN}$ & TN & 0,31 & 0,41 & 0,45 & \\
\hline
\end{tabular}

Keterangan: Angka yang diikuti oleh huruf yang sama pada kolom yang sama menunjukan tidak berbeda nyata pada taraf $5 \%$ uji BNT 


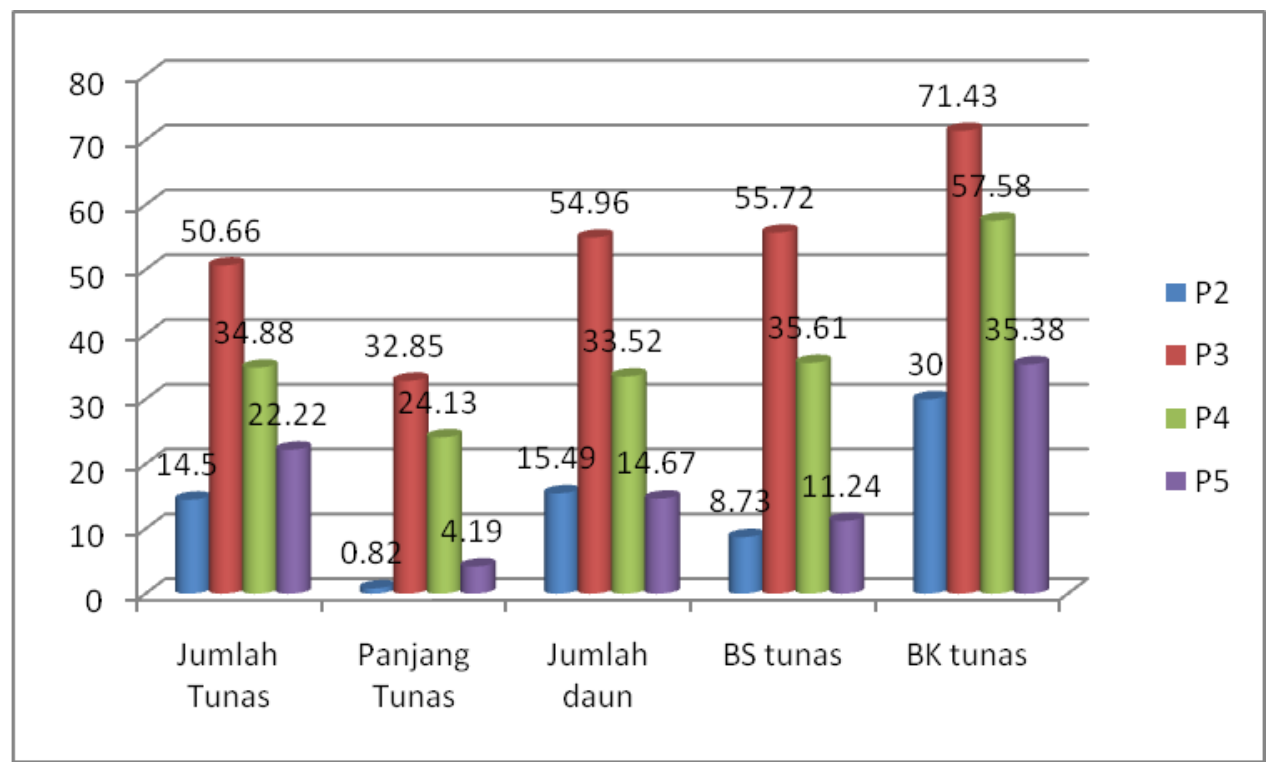

Gambar 1. Rata-rata persentase peningkatan lama perendaman pada ektrak tauge terhadap pertumbuhan jumlah tunas, panjang tunas, Jumlah daun, Berat Segar Tunas dan Berat Kering Tunas Stek Lada

Hasil penelitian menunjukkan pengaruh yang paling tinggi terhadap bahwa pada perlakuan P3 (lama prosentase peningkatan pertumbuhan perendaman 3 jam) menunjukan jumlah tunas $(50,66 \%)$, panjang tunas pengaruh yang paling tinggi terhadap (32,85\%), jumlah daun $(54,96 \%)$, rata-rata pertumbuhan jumlah tunas Berat Segar tunas $(55,72 \%)$ dan Berat $(2,28)$, panjang tunas $(17,05 \mathrm{~cm})$, Kering tunas $(71,43 \%)$. Hal ini jumlah daun (3.91), Berat Segar tunas $(4,37 \mathrm{~g})$ dan Berat Kering tunas $(0,74)$ dibandingkan dengan perlakuan lainya pada umur pengamatan $8,10,12$ minggu setelah tanam.

Berdasarkan Gambar 1 Berat segar dan Berat Kering tunas sebagai pembandingan dalah yang berbeda, dimana peningkatan perlakuan perendaman selama 1 jam, lama perendaman dari P2 (2 jam) dimana perlakuan P3 (lama ditingkatkan ke P3(3 jam) semakin perendaman 3 jam) menunjukan meningkat,namun ditingkatkan lama 
perendaman menjadi 4 jam dan 5 jam menunjukkan prosentasi yang lebih rendah. Hal ini diduga disebabkan kemampuan jaringan tanaman dalam mengabsorsi air beserta zat-zat yang terkandung berkaitan dengan lama perendaman pada ekstrak tauge yang mengandung hormon tumbuh auksin yang berfungsi mendorong perpanjangan sel, pembelahan sel, diferensiasi jaringan xylem dan floem memiliki kapasitas daya absorbsi, sehingga berpengaruh terhadap pertumbuhan akar dan tunas pada stek. Akan tetapi peningkatan lama perendaman (P4 dan P5), menunjukkan prosentase pertumbuhan tunas yang lebih rendah, hal tersebut menunjukkan bahwa jika jaringan menyerap auksin melebihi batas kemampuan jaringan, sehingga pengaruhnya menjadi linier negative atau adanya rata-rata prosentase pertumbuhan yang lebih rendah.

Didukung dengan hasil Penelitian Sudrajat, $\mathrm{H}$ dan Hartato Widodo (2011) yang menyatakan bahwa pengambilan auksin oleh tanaman dari media kedalam jaringan tanaman berlangsung secara proposional sesuai dengan konsentrasi senyawa tersebut dan lama proses berlangsung.

Hal ini sejalan dengan pendapat Kusdianto, Wahyu, Beno (2012), bahwa keberhasilan stek dipengaruhi konsentrasi dan lama perendaman yang diberikan. Apabila konsentrasi tinggi dilakukan dalam waktu yang singkat, tetapi pada konsentrasi rendah dibutuhkan waktu perendaman yang lama.

Hal ini menunjukan bahwa hormon tumbuh yang terkandung dalam eksrak tauge bereaksi memacu pembelahan sel dan pemanjangan sel dimana auksin menyebabkan putusnya ikatan selulosa yang menyebabkan dinding sel merengang sehingga air mudah masuk dan terjadi pemanjangan sel yang mengarah pada meristem pucuk dan primodial daun akan meningkatkan panjang tunas yang menyebabkan pertumbuhan jumlah daun terjadi signifikan. Pada perlakuan P5 rata-rata prosentase pertumbuhan terjadi penurunan hal ini disebabkan karena auksin yang terserap oleh tanaman terlalu berlebihan sehingga pertumbuhan stek menjadi terhambat. Hal ini sesuai dengan pendapat Abdullah, 
Murdaningsih : Uji lama perendaman stek lada pada ekstrak tauge

Maulana Wulandari, Nirwana (2019) menyatakan bahwa pengambilan Senyawa auksin oleh tanaman dari dalam larutan kedalam jaringan tanaman dipengaruhi oleh konsentrasi ZPT yang diberikan dan lamanya proses penyerapan berlangsung

Lama perendaman dengan konsentrasi yang optimum dapat meningkatkan sintesis protein. Protein yang terbentuk tersebut akan digunakan sebagai bahan penyusun organ tanaman seperti akar batang dan daun. Banyaknya jumlah daun dipengaruhi oleh panjang tunas dan jumlah tunas yang tumbuh. Dengan demikian hipotesis dua tebukti bahwa lama perendaman 3 jam berpengaruh

Lama perendaman serta konsentrasi yang diberikan pada stek mempengaruhi pertumbuhan stek tanamann dimana hormon tumbuh berperan dalam proses metabolisme sehingga pertumbuhan akar dan tunas terjadi signifikan yang ditandai dengan banyaknya jumlah tunas dan panjang tunas yang berhubungan erat dengan bobot segar tunas dan bobot kering tunas. Kondisi yang demikian kita berasumsi bahwa banyaknya nyata terhadap variabel pertumbuhan jumlah daun.

Hal ini sesuai dengan pendapat Amilah danAstuti (2006), yang mengatakan bahwa ekstrak tauge mengandung hormon tumbuh auksin, sitokinin, dan giberalin yang berfungsi sebagai pembelahan sel, perpanjangan sel, dan diferensiasi jaringan xylem dan fioem. Hormon eksogen bersifat menghambat pertumbuhan pada kadar rendah tertentu zat pengatur tumbuh akan mendorong pertumbuhan, sedangkan pada kadar yang lebih tinggi akan menghambat pertumbuhan, meracuni, bahkan mematikan tanaman.

tunas dan semakin panjang tunas dapat berpengaruh terahadap berat segar tunas dan berat kering tunas yang merupakan akumulasi bahanbahan organik hasil fotosintesis serta penyerapan unsur hara dan air oleh akar tanaman.

Hal ini sejalan dengan pendapat Lakitan (2006) yang menyatakan bahwa berat segar tunas dan berat kering tunas merupakan akumulasi fotosintat dari dari daun 
AGRICA, VOL. 12, NO. 2 (2019)

dan unsur-unsur hara yang diserap oleh akar untuk pertumbuhan stek.

\section{ResponPertumbuhan} AkarStekTanamanLada

Berdasarkan hasil analisis statististik menunjukan bahwa perendaman ekstrak tauge dengan konsentrasi $300 \mathrm{ml} / \mathrm{l}$ air dapat memberi pengaruh yang sangat nyata terhadap jumlah akar dan panjang akar pada umur 6,8,10,12 minggu setelah tanam dapat di lihat pada tabel Tabel 2.

Tabel 2.Respon lama Perendaman padaEkstrak Tauge Terhadap Pertumbuhan Jumlah akar, panjang akar, Berat Segar AkardanBeratKering Akar stek tanaman lada

\begin{tabular}{|c|c|c|c|c|c|c|c|}
\hline \multirow{2}{*}{ variabel } & \multirow{2}{*}{ perlakuan } & \multicolumn{5}{|c|}{ umur pengamatan mst } & \multirow{2}{*}{ rata-rata } \\
\hline & & 4 & 6 & 8 & 10 & 12 & \\
\hline jumlah & $1 \mathrm{Jam}$ & 4,0 & $5,3 \mathrm{a}$ & $7,0 \mathrm{a}$ & $9,5 \mathrm{a}$ & $10,3 \mathrm{a}$ & 7,46 \\
\hline \multirow[t]{4}{*}{ akar } & $2 \mathrm{Jam}$ & 4,5 & $5,3 \mathrm{a}$ & $6,5 \mathrm{a}$ & $7,8 \mathrm{a}$ & $9,3 \mathrm{a}$ & 6,68 \\
\hline & 3 Jam & 4,8 & $9,0 \mathrm{c}$ & $23,3 \mathrm{c}$ & $17,3 \mathrm{c}$ & $10,0 \mathrm{a}$ & 15,03 \\
\hline & 4 Jam & 4,0 & $7,3 \mathrm{~b}$ & 11,3 & $12,0 \mathrm{~b}$ & $9,3 \mathrm{a}$ & 8,92 \\
\hline & $5 \mathrm{Jam}$ & 4,5 & $6,0 \mathrm{a}$ & $7,8 \mathrm{a}$ & $6,3 \mathrm{a}$ & $7,5 \mathrm{a}$ & 6,18 \\
\hline BNT 5\% & & Tn & 1,67 & 3,92 & 4,64 & 5,49 & \\
\hline panjang & $1 \mathrm{Jam}$ & 4,9 & 6,8 & $11,8 \mathrm{a}$ & $11,2 \mathrm{a}$ & $12,5 \mathrm{a}$ & 9,45 \\
\hline \multirow[t]{4}{*}{ akar } & 2 Jam & 5,9 & 7,2 & $13,8 \mathrm{a}$ & $11,5 \mathrm{a}$ & $14,5 \mathrm{a}$ & 10,38 \\
\hline & $3 \mathrm{Jam}$ & 5,5 & 10,3 & $23,4 \mathrm{c}$ & $21,3 \mathrm{~b}$ & $25,7 \mathrm{c}$ & 17,23 \\
\hline & 4 Jam & 5,5 & 8,8 & $20,7 \mathrm{~b}$ & $14,9 \mathrm{a}$ & $19,4 \mathrm{~b}$ & 13,86 \\
\hline & $5 \mathrm{Jam}$ & 4,8 & 7,9 & $16,4 \mathrm{a}$ & $11,2 \mathrm{a}$ & $17,0 \mathrm{a}$ & 11,46 \\
\hline BNT 5\% & & $\mathrm{TN}$ & $\mathrm{TN}$ & 3,46 & 4,27 & 5,87 & \\
\hline Bobot & 1 Jam & 0,4 & 0,4 & $0,4 \mathrm{a}$ & $0,8 \mathrm{a}$ & $1,0 \mathrm{a}$ & 0,55 \\
\hline Segar & 2 Jam & 0,2 & 0,4 & $0,6 \mathrm{a}$ & $0,9 \mathrm{a}$ & $1,0 \mathrm{a}$ & 0,62 \\
\hline \multirow[t]{3}{*}{ Akar } & 3 Jam & 0,6 & 1,0 & $2,0 \mathrm{c}$ & $1,7 \mathrm{~b}$ & $2,7 \mathrm{~b}$ & 1,61 \\
\hline & 4 Jam & 0,6 & 0,4 & $1,3 \mathrm{ab}$ & $1,4 \mathrm{a}$ & $1,6 \mathrm{a}$ & 1,06 \\
\hline & 5 Jam & 0,1 & 0,3 & $0,8 \mathrm{a}$ & $0,8 \mathrm{a}$ & $1,1 \mathrm{a}$ & 0,62 \\
\hline BNT 5\% & & TN & $\mathrm{TN}$ & 0,66 & 0,61 & 0,91 & \\
\hline Bobot & 1 Jam & 0,03 & 0,10 & $0,08 \mathrm{a}$ & $0,13 \mathrm{a}$ & $0,13 \mathrm{a}$ & 0,09 \\
\hline Kering & 2 Jam & 0,08 & 0,10 & 0,13 & $0,13 \mathrm{a}$ & $0,25 \mathrm{ab}$ & 0,16 \\
\hline \multirow[t]{3}{*}{ Akar } & 3 Jam & 0,13 & 0,40 & $0,30 \mathrm{c}$ & $0,25 \mathrm{~b}$ & $0,43 \mathrm{c}$ & 0,30 \\
\hline & 4 Jam & 0,10 & 0,20 & $0,20 \mathrm{~b}$ & $0,15 \mathrm{a}$ & $0,15 \mathrm{a}$ & 0,12 \\
\hline & 5 Jam & 0,05 & 0,18 & $0,20 \mathrm{ab}$ & $0,13 \mathrm{a}$ & $0,15 \mathrm{a}$ & 0,14 \\
\hline BNT 5\% & & $\mathrm{TN}$ & $\mathrm{TN}$ & 0,08 & 0,11 & 0,12 & \\
\hline
\end{tabular}

Keterangan: angka yang diikuti oleh huruf yang sama pada kolom yang sama menunjukan tidak berbeda nyata pada taraf $5 \%$ uji BNT 
Murdaningsih : Uji lama perendaman stek lada pada ekstrak tauge

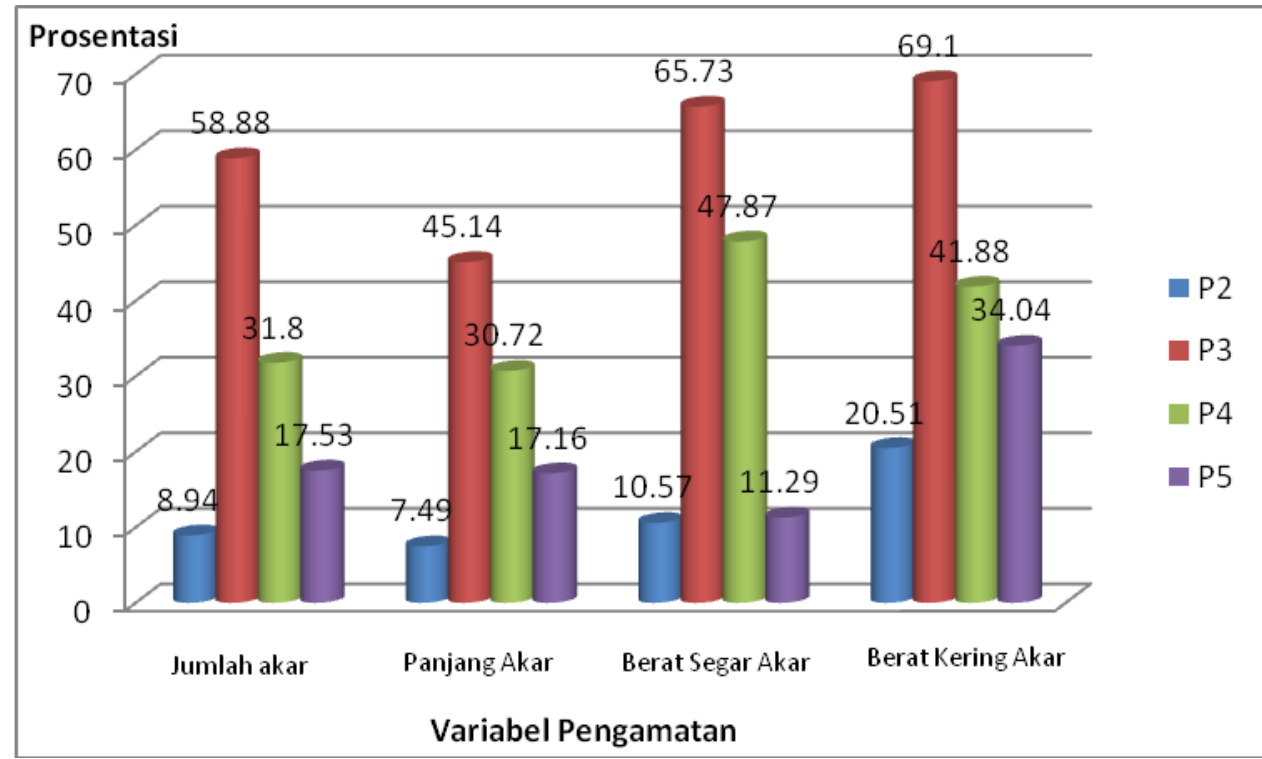

Gambar 2. Rata-rata persentasi peningkatan lama perendaman padaekstrak tauge terhadap pertumbuhan jumlah akar, panjang akar, Berat Segar AkardanBeratKeringAkarStekLada.

Hasil penelitian menunjukkan bahwa pada perlakuan P3 (lama perendaman3 jam) menunjukan pengaruh yang paling tinggi terhadap rata-rata pertumbuhan jumlah akar $(15,03)$, panjang akar $(17,23 \mathrm{~cm})$, Berat Segar akar $(1,61 \mathrm{~g})$ dan Berat Kering akar $(0,30 \mathrm{~g})$ dibandingkan dengan perlakuan lainya pada umur pengamatan $8,10,12$ minggu setelah tanam

Berdasarkan Gambar 2 sebagai pembanding adalah perlakuan lama perendaman satu jam (P1), dimana perlakuan perendaman 3 jam (P3) menunjukkan pengaruh yang paling tinggi terhadap pertumbuhan akar stek tanaman lada pada variable jumlah akar (58,88\%), panjang akar $(45,14 \%)$, Berat Segar akar ( 65,73\%) dan Berat kering akar $(69,10 \%)$. Dimana semakin ditingkatkan lama perendaman,memberikan rata-rata prosentase pertumbuhan akar yangyanglebihrendah (P4 dan P5) .Hal ini disebabkan karena hormon tumbuh yang terdapat dalam ekstrak tauge bekerja secara maksimal pada pengenceran dan lama perendaman yang dibutuhkan untuk proses pembelahan sel, perpanjangan sel dan diferensiasi sel pada stek sesuai 
kebutuhan tanaman sehingga terjadi peningkatan pertumbuhan, dimana hormon auksin berfungsi membantu dalam mempercepat proses pertumbuhan dan perkembangan tanaman.Apabia auksin yang diabsosbsi stek melebihi kebutuhan, tidak dapat digunakan jaringan tanaman, atau bahkan akan dapat menghambat proses pertumbuhan akar, terbukti rata-rata prosentase akar pada stek lada menjadi lebih rendah.

Hal ini sesuai dengan pendapat Abdullah, Maulana Wulandari, Nirwana. (2019) bahwa pengunaan zat pengatur tumbuh perlu memperhatikan konsentrasi dan lama perendaman, zat pembawanya, waktu pengunaan, dan bagian tanaman yang diperlukan untuk dapat mengrangsang terbentuknya akar.

Hasil penelitian Putra, F., Indriyanto dan Melya Riniarti (2014), bahwa kandungan rootnone-f adalah senyawa IBA yang merupakan senyawa yang memiliki daya kerja seperti auksin (IAA) yaitu pada konsentrasi yang tepat akan meningkatkan pembelahan, perpanjangan sel dan diferensiasi sel. Didukung penelitian Budianto $d k k$
(2013), menyatakan bahwa perlakuan lama perendaman dengan IBA (Indole Butryc Acid) yang mempunyai kandungan hormon tumbuh auksin $(0,057 \%)$ di rendam selama 3 jam memberikan pengaruh secara nyata terhadap parameter panjang akar $(6,65)$ jumlah daun $(5,10)$ dan bobot kering akar $(6,37 \mathrm{~g})$ pada tanaman stek sirih merah

Hal ini menunjukan bahwa lama perendaman pada ekstrak tauge yang mengandung hormon tumbuh dengan konsentrasi yang optimal akan mempengaruhi pertumbuhan dan perkemangan stek tanaman yang ditandai dengan banyaknya jumlah akar dan panjang akar. Dimana auksin diketahui mengintensifkan pembentukan akar sehingga terjadi peningkatan jumlah akar dan panjang akar yang berhubungan erat dengan berat segar akar dan berat kering akar.

Berat segar dan berat kering tanaman merupakan akumulasi berupa air dan unsur hara yang diserap untuk pertumbuhan stek tanaman. Dan ditambahkan oleh AmilahdanAstuti (2006), yang mengatakan bahwa ekstrak tauge mengandung hormon tumbuh auksin, 
sitokinin, dan giberalin yang berfungsi sebagai pembelahan sel, perpanjangan sel, dan diferensiasi jaringan xylem dan fioem.Muswita (2011), mengatakan bahwa penambahan auksin eksogen akan meningkatkan kandungan auksin endogen dalam jaringan stek sehingga mampu menginisiasi sel untuk tumbuh dan berkembang selanjutnya akan berdiferensiasi membentuk akar

\section{SIMPULAN}

Berdasrkan hasil penelitian respon pertumbuhan stek tanaman lada (Piper nigrum L) akibat lama perendaman ekstrak tauge dapat disimpulkan sbb:

1. Pemberian

perlakuan konsentrasi $(300 \quad \mathrm{ml} / \mathrm{l}$ air $)$ dengan lama perendaman 3 jam pada ekstrak tauge berpengaruh sangat nyata terhadap persentase (\%) pertumbuhan jumlah tunas (50,66\%), panjang tunas $(32,85 \%)$, jumlah daun (54,96\%), jumlah akar $(58,88 \%)$, panjang akar $(45,14 \%)$, bobot segar tunas $(71,43 \%)$, bobot kering tunas
$(55,72 \%)$, bobot segar akar $(65,73 \%)$, bobot kering akar $(69,10 \%)$ pada umur $8,10,12$ minggu setelah tanam.

2. Perlakuan lama perendaman pada ekstrak tauge berpengaruh sangat nyata terhadap rata-rata pertumbuhan pada jumlah tunas (2,28 helai), panjang tunas $(17,05 \mathrm{~cm}), \quad$ jumlah daun (3,91 helai), jumlah akar (15,03 helai), panjang akar $(17,23 \mathrm{~cm})$, bobot segar tunas $(4,37 \mathrm{~g})$, bobot kering tunas $(0,74 \mathrm{~g})$, bobot segar akar $(0,61 \mathrm{~g})$, bobot kering tunas $(0,30 \mathrm{~g})$

\section{UCAPAN TERIMA KASIH}

Pada kesempatan ini penulis ingin mengucapkan terima kasih kepada semua pihak yang telah membantu dengan caranya masingmasingdalam melengkapi tulisan ini.

\section{DAFTAR PUSTAKA}

\begin{tabular}{|c|c|c|}
\hline Abdullah, & Maulana & Wulandari, \\
\hline Nirwana. & 2019 & Pengaruh \\
\hline Ekstrak & Tanaman & Sebagai \\
\hline Sumber & ZPT Alami & Terhadap \\
\hline Pertumbu & Setek & Tanaman \\
\hline
\end{tabular}


Lada (Piper nigrumL.). Jurnal Agrotek Vol. 3 No. 1 Maret 2019.Fakultas Pertanian Universitas Muslim Indonesia

Amilah dan Astuti Y. 2006. Pengaruh Konsentrasi ekstrak tauge dan kacang hijau pada media vacin and went (vw) terhadap pertumbuhan kecambah anggrek bulan. https://andreasd amanik14.

Budianto E. A, Kaswan Badami, Ahmad Arsyadmunir. 2013. Pengaruh Kombinasi Macam zpt Dengan Lama Perendaman Yang Berbeda Terhadap Keberhasilan Pembibitan Sirih Merah (Piper crucatum Ruiz \&Pav) Secara Stek. Jurnal Penelitian Agrovigor Volume 6 No. 2 ISSN 19795777. Fakultas Pertanian Universitas Trunojoyo Madura.

Direktotat Jendral

Perkebunan.2016.Statistik

Perkebunan Indonesia 2015 2017 lada. Dirktorat jendral Perkebunan. Jakarta.

Direktorat Budidaya Tanaman Rempah dan pagar; (Diratpahgar). 2008. Budidaya Lada yang baik dan sehat.http:// Ditjenbun.Deptan,go.id/.

Gomez, K.A.\& A.A. Gomez. 2007. Prosedur Statistika untuk Penelitian Pertanian (Terjemahan A.Sjamsuddin \& J.S. Baharsyah Edisi Kedua. UI Press,Jakartta.

Kusdianto, Wahyu Beno. 2012. Efektivitas konsentrasi IBA
(Indole Butyric Acid) dan lama perendaman terhadap pertumbuhan stek jeruk nipis (Citrus aurantiifolia Swingle). Skripsi Pada Program Studi Agroteknologi, Pertanian. Universitas Sebelas Maret.

Lakitan, B, 2006, Dasar-Dasar Fisiologi Tumbuhan, Raja Grafindo perkasa, Jakarta

Muswita. 2011. Pengaruh konsentrasi bawang merah (Allium cepa L.) terhadap pertumbuhan setek gaharu (Aquilaria malaccencis Oken). Universitas Jambi Seri Sains volume 13 (1):63-68.

Putra, F., Indriyanto dan Melya Riniarti. 2014. Keberhasilan Hidup Stek Pucuk Jabon dengan Pemberian Beberapa Konsentrasi Rootone F. Jurnal Sylva Lestari Vol.2 No. 2 : 3340. Universitas Lampung.

Rauzana A, Marliana dan Mariana, 2017 pengaruh pemberian eksrak tauge terhadap pertumbuhan bibit lada. Jurnal Agrotropika Hayati. Vol 4 .No 3. Hal 178- 186.

Sari, 2011, pertumbuhan stek lada (piper nigrum L) Yang Distimulir Dengan Hormon Tumbuh Pada Berbagai Media Tanam Organik, Jurnal Agrisistem, Vol 3, No 2 hal 167-170.

Sudrajat, $\mathrm{H}$ dan Harto Widodo. 2011. Pengaruh Konsentrasi dan Lama Perendaman Rootone F Pada Pertumbuhan Pule Pandak. Balai Besar 
Murdaningsih : Uji lama perendaman stek lada pada ekstrak tauge

Penelitian dan Pengembangan

Obat dan Tanaman Obat.

Surakarta. 